\title{
Implementation of Character Education in Planting Student Nationalism in The Era of Independent Learning
}

\section{Edi Siswanto}

SMP N 2 Nalumsari

edisiswanto184@gmail.com.

\section{Article History}

accepted 1/09/2020

approved 4/10/2020

published 1/12/2020

\begin{abstract}
Seeing the existing problems with the character crisis in this country, as an effort for social studies teachers to implement character education in instilling the nationalism of students in the era of independent learning. The method used in this research is a qualitative descriptive method, where descriptive research in this case is a study that aims to describe the policy of independent learning as an effort to improve the quality of education and the attitude of nationalism. The results of this study indicate that the attitude of nationalism which is part of the character values really needs to be possessed by students, the role of the teacher is very important in shaping the character of students who have a nationalistic attitude. The teacher's role implementation can be reflected in the teacher's personality, because the teacher is the main factor and influences the learning process of students. The efforts of history teachers in forming students' nationalistic attitudes, namely linking with the scope, historical material and lesson plans for history subjects, the methods used by teachers in instilling the existing values of nationalism. Learning media used by teachers in an effort to form student nationalism attitudes.
\end{abstract}

Keywords: Merdeka belajar, character education, teachers, nationalism

\begin{abstract}
Abstrak
Melihat permasalahan yang ada akan krisis karakter di Negara ini, maka sebagai salah satu upayanya guru IPS Sejarah perlu melakukan implementasi pendidikan karakter dalam menanamkan nasionalisme peserta didik di era merdeka belajar. Metode yang digunakan dalam penelitian ini adalah metode deskriptif kualitatif, dimana penelitian deskriptif dalam hal ini merupakan penelitian yang bertujuan untuk menggambarkan kebijakan merdeka belajar sebagai usaha meningkatkan mutu Pendidikan dan sikap nasionalisme. Hasil dari penelitian ini menunjukan sikap Nasionalisme yang merupakan bagian dari nilai karakter sangat perlu dimiliki oleh peserta didik, peranan guru menjadi sangat penting dalam pembentukan karakter siswa yang mempunyai sikap nasionalisme. Impelentasi peran guru bisa dicerminkan dengan kepribadian guru, karena guru merupakan faktor utama dan berpengaruh terhadap proses belajar peserta didik. Upaya guru sejarah dalam pembentukan sikap nasionalisme peserta didik yaitu mengkaitkan dengan ruang lingkup, materi sejarah dan RPP mata pelajaran sejarah, metode-metode yang digunakan oleh guru dalam menanamkan nilai-nilai nasionalisme yang ada. Media pembelajaran yang digunakan oleh guru dalam upaya pembentukan sikap nasionalisme siswa.
\end{abstract}

Kata Kunci : Merdeka belajar, pendidikan karakter, guru, nasionalisme

Social, Humanities, and Education Studies (SHEs): Conference Series https://jurnal.uns.ac.id/shes
p-ISSN 2620-9284

e-ISSN 2620-9292 


\section{PENDAHULUAN}

Cita-cita Bangsa Indonesia adalah menjadi negara besar, kuat, disegani dan dihormati keberadaannya di tengah bangsa-bangsa di dunia. Setelah 75 tahun merdeka pencapaian cita-cita ini belum menunjukkan tanda-tanda menggemberikan. Optimisme mencapai cita-cita itu terus dihadapkan pada berbagai macam tantangan. Semangat nasionalisme yang dimiliki founding fathers bangsa ini dalam menegakkan dan membangun Negara Kesatuan Repulik Indonesia (NKRI) seakan-akan tidak dapat diimbangi karena begitu banyaknya persoalan-persoalan yang harus diselesaikan bangsa ini. Demikian juga halnya terhadap nilai-nilai kebangsaan dan moral, dalam beberapa hal mulai bergeser keluar dari norma-norma yang dijunjung tinggi bangsa Indonesia. (Prayitno dan Manullang 2011)

Untuk mengatasi permasalahan tersebut, pemerintah harus membina dan membangun bangsa dengan menanamkan nilai-nilai positif (alih-alih disebut pendidikan karakter), agar bangsa Indonesia memiliki karakter positif dan mampu bersaing dengan negara-negara lain di era globalisasi.

Sikap Nasionalisme yang merupakan bagian dari nilai karakter sangat perlu dimiliki oleh peserta didik, peranan guru menjadi sangat penting dalam pembentukan karakter siswa yang mempunyai sikap nasionalisme. Seorang guru dalam proses belajar mengajar bukanlah sekedar menyampaikan materi tetapi juga harus berupaya agar materi pelajaran yang disampaikan menjadi kegiatan yang menyenangkan serta dapat mengupayakan tumbuhnya nilai karakter pada diri siswa. Faktor kemampuan sangat penting dimiliki oleh setiap guru dalam menanamkan nilainilai karakter siswa. Semakin tinggi kemampuan guru dalam melaksanakan proses belajar-mengajar, semakin tinggi pula keberhasilan guru dalam menanamkan nilai karakter siswa.

Sikap nasionalisme siswa mengalami penurunan, hal ini terlihat dari fenomena siswa sering acuh dan tidak mau tahu apa yang terjadi di sekitarnya. Permasalahan ini menjadi tugas guru, siswa, orang tua dan pemerintah. Lembaga sekolah dalam hal ini guru mempunyai tugas dalam pembentukan sikap nasionalisme siswa. Salah satu adalah tugas guru Sejarah melalui pembelajaran yang diajarkan di dalam kelas, sehingga siswa memiliki sikap nasionalisme. Adanya pendidikan karakter yang diarahkan pemerintah turut menunjang dalam pembentukan nasionalisme.

Mata pelajaran Sejarah memiliki arti strategis dalam pembentukan watak dan peradaban bangsa yang bermartabat serta dalam pembentukan manusia Indonesia yang memiliki rasa kebangsaan dan cinta tanah air. Pembentukan kepribadian nasional beserta identitas danjati diri tidak akan terwujud tanpa adanya pengembangan kesadaran sejarah sebagai sumber inspirasi dan aspirasi.

Pendidikan yang berkualitas dapat diperoleh dari proses pembelajaran yang bermutu. Pembelajaran yang bermutu merupakan pembelajaran yang memperhatikan aspek kognitif (otak), afektif (sikap), dan psikomotorik (perilaku) secara seimbang, karena pendidikan bertugas untuk mencetak generasi yang unggul dengan intelegensi spiritual dan intelegensi emosional yang baik. Hal ini sejalan dengan amanat pendidikan dalam UU No. 20 Tahun 2003 tentang pendidikan nasional yang fungsi utamanya adalah untuk mengembangkan kemampuan dan mencetak karakter yang unggul, serta bangsa yang bermartabat untuk mencerdaskan kehidupan berbangsa.

Berdasarkan fungsi pendidikan diatas, maka untuk mewujudkannya pemerintah Indonesia mengeluarkan kebijakan sistem pendidikan yang baru. Program tersebut akrab dikenal dengan istilah 'Merdeka Belajar'. Dengan memahami konsep merdeka belajar yang didukung dengan adanya pendidikan karakter, diharapkan pendidikan di Indonesia dapat menjadi lebih maju, berkualitas, dan dapat melahirkan generasi emas yang tangguh dalam mengahadapi berbagai tantangan di masa depan.

Praktik pendidikan di Indonesia selama ini lebih banyak terfokus pada pengembangan keterampilan dan ilmu pengetahuan, dibandingkan dengan 
pengembangan karakter luhur dan rasa kebangsaan warga negara. Selama ini nampak bahwa pendidikan di Indonesia terlalu menekankan aspek intelektualitas, kurang memperhatikan aspek moralitas. Pendidikan kita terlalu berfokus pada pencapaian angka-angka, entah itu pada aspek pengetahuan, tak terkecuali pada aspek keterampilan. Menangani persoalan tersebut, maka implementasi pendidikan karakter sangat diperlukan pada era merdeka belajar, maka artikel melakukan analisis implementasi pendidikan karakter dalam menanamkan nasionalisme peserta didik di era merdeka belajar.

\section{Merdeka Belajar}

Nadiem Anwar Makariem telah menetapkan beberapa hal terkait dengan Pendidikan di Indonesiasebagai upaya menghasilkan sumber daya manusia yangbermutudan berkualitas. Program tersebut dikenal dengan istilah "Merdeka Belajar". Merdeka Belajar adalah sebuah sistem pendidikan yang di dalamnya mengutamakan kebebasan, baik pada guru maupun peserta didik. Maknanya sistem pembelajaran akan berganti, dari yang awalnya tatap muka di dalam kelas akan menjadi di luar kelas (out door). Suasana pembelajaran akan berjalan lebih rileks, karena siswa dapat mendiskusikan materi bersama guru, belajar dengan outing class, siswa tidak hanya sekedar mendengarkan penjelasan materi guru, pembentukan karakter siswa yang berani, mandiri, berakhlak, kompetisi, dan tidak hanya mengandalkan sistemranking. Pada kenyataannya setiap anak memiliki bakat dankecerdasan yang berbeda-beda sesuai dengan bakat dan minatnya.

Era merdeka belajar dapat diartikan sebagai masa di mana guru dan siswa memiliki kemerdekaan atau kebebasan berfikir, bebas dari beban pendidikan yang membelenggu agar mampu mengembangkan petensi diri mencapai tujuan pendidikan. Menteri Pendidikan dan Kebudayaan periode 2019-2024, Nadiem Makarim, memperkuat program pendidikan "merdeka belajar" dengan meluncurkan 4 kebijakan pokok, yaitu: pertama, Ujian Sekolah Berbasis Nasional (USBN) akan diganti dengan assessment yang diselenggarakan oleh sekolah berbasis portofolio. Kedua, Ujian Nasional (UN) akan dihapus dan diganti assesment kompetensi minimum dan survei karakter. Ketiga, terkait Rancangan Pelaksanaan Pembelajaran (RPP), guru dapat bebas memilih, membuat, menggunakan, dan mengembangkan format RPP yang berisi tujuan pembelajaran, kegiatan pembelajaran, dan assessment. Keempat, Penerimaan Peserta Didik Baru (PPDB) yang lebih fleksibel di mana setiap daerah diberi wewenang dalam menentukan presentase PPDB. Berdasarkan hal tersebut, program pendidikan "merdeka belajar" memberi paradigma baru bahwa nantinya pendidikan tidak lagi hanya sebatas penilaian kognitif saja, namun juga penilaian afektif dan psikomotorik. (Wartoni 2019)

Sistem pembelajaran akan didesain sedemikian rupa agar karakter siswa terbentuk, dan tidak terfokus pada sistem perangkingan yang menurut beberapa penelitian hanya meresahkan, tidah hanya bagi guru tetapi juga anak dan orang tuanya. Selain itu, dengan perangkingan nantinya juga akan muncul diskriminasi dimana ada pelebelan antara si pintar dan si bodoh. Hal ini tentu sangat keliru jika diterapkan dalam dunia pendidikan, karena pada hakekatnya anak memiliki kecerdasan masing-masing di dalam dirinya atau yang sering disebut dengan multiple intelegent. Multiple intelegent merupakan teori yang dikembangkan oleh Dr. Howard Gardner seorang ahli psikologi modern di Harvard University, di mana menurut Gardner kecerdasan diartikan sebagai kapasitas untuk memecahkan masalah dan untuk menciptakan produk di lingkungan yang kondusif dan alamiah. Potensi yang dimilik oleh anak sekecil apapun harus dihargai, banyak anak yang memiliki hambatan atau kesulitan dalam belajar akan tetapi jika kecerdasannya dihargai dan 
terus dikembangkan maka anak tersebut akan menjadi anak unggulan pada bidangnya. Sehingga nantinya akan terbentuk pribadi yang kompeten, serta memiliki karakter yang tertanam dalam dirinya.

Pada dunia pendidikan, merdeka belajar mencakup kondisi merdeka dalam mencapai tujuan, metode, materi, dan evaluasi pembelajaran baik bagi guru maupun siswa (Lubis 2020). Hal ini bertujuan untuk mempersiapkan anak-anak yang saat ini duduk dibangku SD, SMP, dan SMA dalam menghadapi berbagai tantangan di masa depan. Mengingat bahwa kelak pada 2045 Indonesia telah mencapai usia "Emas", yaitu 100 tahun kemerdekaan NKRI. Pada usia satu abad tersebut, Indonesia harus mampu mengatasi berbagai macam permasalahan. Perbaikan. Kualitas sumber daya manusia menjadi kunci utama dalam mewujudkan Indonesia emas 2045.

Era digital yang melaju dengan pesat membuka pertukaran informasi dan budaya tanpa ada batasan. Hal ini, membawa dampak dari segi positif dan segi negatif. Aspek positif yangdidapat,seperti adanya kemudahan dalam mengakses ilmu pengetahuan, teknologi, serta informasi yang membangun. Namun, disisi lain juga terdapat dampak negatif yang menyertainya, misalnya dapat menggerus budaya dan identitas bangsa Indonesia.

Dengan demikian pendidikan karakter sangat dibutuhkan keberadaannya dalam mencetak generasi bangsa yang memiliki intelektual tinggi, inovatif, dan kreatif, sesuai yang tertuang dalam kebijakan program Merdeka Belajar yang telah ditetapkan oleh pemerintah. Karena peranan orang tua tidak dapat tergantikan dengan teknologi yang canggih.

\section{Pendidikan Karakter}

Pendidikan karakter merupakan suatu penanaman nilai-nilai karakter kepada warga sekolah yang meliputi komponen pengetahuan, kesadaran dan kemauan untuk melaksanakan nilai-nilai tersebut. Pendidikan karakter dapat dimaknai dengan " the deliberate use og all dimensions of school life to foster optimal character development". Dalam pendidikan karakter di sekolah ,semua komponen (pemangku pendidikan) harus dilibatkan, komponen-komponen pendidikan sendiri yaitu isi kurikulum, proses pembelajaran dan penilaian, penangganan dan pengelolaan mata pelajaran, pengelolaan sekolah, pelaksanaan aktivitas atau kegiatan ko-kurikuler, pemberdayaan sarana dan prasarana, pembiayaan, etos kerja seluruh warga sekolah atau lingkungan (Adisusilo 2012).

Penerapan pendidikan karakter di sekolah sangat di perlukan dan di laksanakan, karena dengan pendidikan karakter di sekolah akan membentuk karakter baru Peserta Didik sesuai dengan karakter yang diinginkan. Pendidkan karakter pada dasarnya dapat diintegrasikan dalam pembelajaran pada setiap mata pelajaran dengan tujuan untuk memperkenalkan nilai-nilai pendidikan karakter di setiap mata pelajaran sehingga menyadari akan pentingnya nilai-nilai tersebut dan penghayatan nilai-nilai ke dalam tingkah laku peserta didik sehari-hari melalui proses pembelajaran, baik yang berlangsung di dalam maupun di luar kelas (Suprapti 2019).

Berdasarkan grand design yang dikembangkan Kemendiknas, secara psikologis dan sosial kultural pembentukan karakter dalam diri individu merupakan fungsi dari seluruh potensi individu manusia (kognitif, afektif, konatif, dan psikomotorik) dalam konteks interaksi sosial kultural (dalam keluarga, sekolah, dan masyarakat) dan berlangsung sepanjang hayat. Konfigurasi karakter ini dapat dikelompokkan ke dalam:

a. Olah hati (spritual and emotional development),

b. Olah pikir (intellectual development),

c. Olah raga dan kinestetik (physical and kinesthetic development), dan 
d. Olah rasa dan karsa (affective and creativity development).

Keempat hal ini tidak dapat dipisahkan satu sama lainnya, bahkan saling melengkapi dan saling terkait. Pendidikan karakter di dalam proses pembelajaran dilaksanakan mulai dari tahap perencanaan, pelaksanaan, dan evaluasi pembelajaran pada semua mata pelajaran. Di antara prinsip-prinsip yang dapat diadopsi dalam membuat perencanaan pembelajaran (merancang kegiatan pembelajaran dan penilaian dalam RPP dan bahan ajar), melaksanakan proses pembelajaran, dan evaluasi dengan prinsip-prinsip pembelajaran kontekstual (Contextual Teaching and Learning) yaitu konsep belajar dan mengajar yang membantu guru dan siswa mengaitkan antara materi yang diajarkan dengan situasi dunia nyata. Sehingga siswa mampu untuk membuat hubungan antara pengetahuan yang dimilikinya dengan penerapannya dalam kehidupan mereka.

Pelaksanaan pendidikan karakter dalam pembelajaran dapat dilakukan dengan pengenalan nilai-nilai, pengintegrasian nilai-nilai ke dalam tingkah laku peserta didik sehari-hari melalui proses pembelajaran baik yang berlangsung di dalam maupun di luar kelas pada semua mata pelajaran. Dengan demikian, kegiatan pembelajaran selain untuk menjadikan peserta didik menguasai kompetensi (materi) yang ditargetkan, juga dirancang dan dilakukan untuk menjadikan peserta didik mengenal, menyadari/peduli, dan mengintegrasikan nilai-nilai dan menjadikannya perilaku.

Tujuan pendidikan karakter adalah penanaman nilai dalam diri siswa dan pembaharuan tata kehidupan bersama yang lebih menghargai kebebasan individu. Tujuan jangka panjangnya adalah mendasarkan diri pada tanggapan aktif kontekstual individu atas impuls natural sosial yang diterimanya, yang pada giliranya semakin mempertajam visi hidup yang akan diraih lewat proses pembentukan diri secara terus-menerus (on going formation). Tujuan jangka panjang ini merupakan pendekatan dialektis yang semakin mendekatkan dengan kenyataan yang ideal, melalui proses refleksi dan interaksi secara terus-menerus antara idealisme, pilihan sarana, dan hasil langsung yang dapat dievaluasi secara objektif. (Kusuma 2007).

\section{METODE}

Berdasarkan permasalahan yang diteliti, jenis penelitian yang digunakan adalah penelitian kualitatif, karena pembahasan ini berusaha mendeskripsikan atau memberikangambaran mengenai gambaran pendidikan karakter oleh guru sejarah dalam menanamkan nasionalisme peserta didik. Hal ini sesuai dengan pendapat Bogdan dan Taylor dalam (Moleong 2009) bahwa analisis kualitatif merupakan proses yang menghasilkan data deskriptif berupa kata-kata tertulis dari orang-orang atau perilaku yang diamati, pendekatan ini diarahkan pada latar dan tersebut yang diamati. Dalam upaya mendapatkan keterangan dan data yang relevan dengan permasalahan yang diteliti, maka informan dalam penelitian ini adalah guru Sejarah, selain guru sejarah informan lainya adalah kepala sekolah, wakil kepala sekolah serta peserta didik.

\section{HASIL DAN PEMBAHASAN}

Pendidikan berarti upaya transformasi ilmu pengetahuan (transfer of knowledge), pengayaan nilai (transfer of value), pengetahuan tentang karakter kebudayaan (transfer of culture), dan penanaman nilai keagamaan (transfer of religius) yang diarahkan pada upaya untuk "memanusiakan manusia". Upaya seperti itulah hakikat pendidikan, yaitu berorientasi pola perubahan perilaku individu agar memiliki nilai-nilai luhur, cerdas dan terampil. Pendidik sebagai pemilik kekuatan moral (moral force), memiliki peran penting dalam meningkatkan potensi peserta didik di sekolah. Pendidik tidak hanya 
menyampaikan pelajarannya (transfer of knowledge), melainkan harus dengan nilainya (transfer of value). Secara sederhana pendidikan dapat dimaknai sebagai usaha membantu peserta didik mengembangkan seluruh potensinya (hati, pikir, rasa, dan karsa, serta raga) untuk menghadapi masa depan (Samani dan Hariyanto 2013).

Ditambahkan kutipan pak Habibie, bahwa pembangunan bangsa itu harus seperti dua sayap pesawat terbang, "sayap sebelah kanan adalah iman dan takwa kepada Tuhan Yang Maha Esa dan sayap kiri adalah pembangunan ilmu dan teknologi. Keduanya harus ada, tidak bisa hanya salah satu saja. Dari dua unsur yang sudah dijelaskan, pendidikan dan karakter serta kutipan dari pak Habibie, generasi milenial perlu dipersiapkan dengan menanamkan pendidikan karakter.

Pendidikan yang diharapkan adalah secara sadar menyiapkan peserta didik dengan kegiatan dan pengajaran yang sesuai dengan tantangan jaman di masa depan (Amri dan Sofan 2013). Satu hal lainnya yang tidak kalah penting dalam pendidikan, proses pembelajaran yang kontekstual akan menjadikan pembelajaran bermakna karena selalu dikaitkan dengan kehidupan nyata dengan konteks lingkungan pribadi, sosial, dan budayanya (Johnson 2002).

Dengan adanya konsep merdeka belajar ini, guru sebagai komponen utama dalam pendidikan memiliki kebebasan secara mandiri untuk menterjemahkan kurikulum sebelum diajarkan kepada para siswa. Maka guru dapat memanfaatkan konsep merdeka belajar ini dengan memberikan pendidikan karakter kepada siswa. Guru lebih tau kebutuhan dari para siswa selama proses pembelajaran, sehingga dapat memberikan pendiikan karakter dengan berbagai metode.

Pada waktu melaksanakan pendidikan karakter oleh guru dalam pembelajaran di sekolah, guru sebetulnya menghadapi persoalan terkait masalah internal guru, selain dihadapkan pada persoalan internal, guru juga mempunyai tantangan eksternal yang harus dihadapinya. Menurut Indra Djati Sidi, Ph.d. dalam bukunya Menuju Masyarakat Belajar, guru mempunyai dua persoalan eksternal, yaitu pertama, krisis etika dan moral anak bangsa, dan yang kedua, tantangan masyarakat global.

Persoalan etika dan moral anak bangsa, sesungguhnya bukan hanya permasalah guru. Namun, jika yang dibidiknya adalah moral pelajar, maka tidak ada alasan guru tidak dilibatkan. Guru sebagai pengajar dan pendidik, memang tidak hanya harus "membina" para murid dari segi kognitif dan psikomotoriknya demi peningkatan nilai angka. Akan tetapi, seorang guru sangat dituntut agar apa yang ia ajarkan dipraktekan oleh para muridnya dalam kehidupan.

Seorang guru harus bisa mengubah pola pikir dan perilaku para siswa agar lebih baik dan mampu menciptakan pelajar yang etis-moralis. Guru adalah orang yang bertanggung jawab atas peningkatan moral pelajar juga kemorosotannya. Dengan demikian, tugas guru tidak terbatas pada pengajaran mata pelajaran, tapi yang paling urgen adalah pencetakan karakter murid. Tantangan persoalan ini memang sangat sulit bagi para guru, keterbatasan kontroling guru pada murid kerap membuatnya kecolongan. Sehingga tidak sedikit murid didikannya yang terbawa arus perilaku amoral diluar pengetahuannya.

Secara umum gambaran peran guru di dalam kelas merupakan salah satu titik awal untuk manarik peserta didik untuk mengikuti setiap pelajaran dengan semangat tinggi. Tentunya berpenampilan menarik bukan hanya menyangkut cara penyampaikan materi pelajaran, tetapi juga menyangkut kebersihan dan kerapian hidup sehari-hari seorang guru. Sesungguhnya guru tidak perlu berbicara banyak untuk mengubah prilaku siswa, dia cukup memperhatikan bagaimana cara bertingkah laku, berpenampilan, dan berhubungan antar sesama

Seorang guru, selain memiliki pemahaman, keterampilan, dan kompetensi mengenai karakter, tetapi jugadituntut memiliki karakter-karakter mulia dalam dirinya sendiri, mempraktikkan dalam keseharian baik di sekolah maupun di masyarakat,dan menjadikannya sebahagian dari hidupnya. Artinya sebelum mengajar atau 
menginternalisasikan karakter kepada peserta didik harus terlebih dahulu memancarkan karakter-karakter mulia dari dalam diri guru khususnya guru sejarah, jadi bagaimana mau mengajari peserta didik tentang pendidikan karakter,sementara guru yang bersangkutan tidak memahami apalagi mempraktekkan dalam kehidupan nyata, jika guru tidak memiliki karakter ia akan gagal dan malahan ditertawakan oleh peserta didiknya.

Upaya guru sejarah dalam pembentukan sikap nasionalisme peserta didik yaitu mengkaitkan dengan ruang lingkup :

a. Materi sejarah, materi sejarah inilah yang telah dianalisis secara detail sehingga dapat diperoleh hasil berupa nilai-nilai nasionalisme dan nilai pendidikan karater dalam pembentukan sikap nasionalisme siswa yang disampaikan oleh guru sejarah.

b. Silabus dan RPP matapelajaran sejarah, Silabus dan RPP merupakan perangkat pembelajaran. Silabus dan RPP sebagai pedoman guru untuk mengajar pada mata pelajaran tertentu yang wajib harus dibuat.

c. Metode-metode yang digunakan oleh guru dalam menanamkan nilai-nilai nasionalisme yang ada

d. Media pembelajaran yang digunakan oleh guru dalam upaya pembentukan sikap nasionalisme siswa.

Pendidikan di Indonesia saat ini lebih mengedepankan penguasaan aspek keilmuan, kecerdasan dan kurang memperhatikan atau mengabaikan pendidikan karakter. Pengetahuan tentang kaidah moral yang didapatkan dalam pendidikan moral atau etika di sekolah-sekolah saat ini semakin ditinggalkan karena kurang perhatian pemerintah terhadap pendidikan karakter.

Gambaran Peranan Guru Sejarah pada Pendidikan Karakter dalam pembentukan sikap nasionalisme peserta didik, dimana guru sebagai pendidik memiliki kedudukan penting dalam pelaksanaan pendidikan karakter. Dalam pembahasan ini difokuskan pada implementasi pembentukan karakter oleh guru sejarah dalam menanamkan rasa nasionalism peserta didik.

Peranan guru dalam pendidikan karakter guna pembentukan sikap nasionalisme siswa dapat dijelaskan dalam lima hal yakni :

a. Keteladanan adalah Guru sebagai model merupakan contoh bagi siswa. Apa yang dilakukan oleh guru sebaiknya dapat menjadi pedoman yang baik bagi siswanya.

b. Inspirator adalah guru mampu membangkitkan semangat untuk maju dan menggerakkan segala potensi yang dimiliki oleh siswa.

c. Motivator adalah kemampuan guru dalam membangkitkan spirit, etos kerja, dan potensi yang luar biasa dalam diri siswa.

d. Dinamisator adalah kemampuan guru untuk mendorong siswa untuk mencapai tujuan dengan kecepatan, kecerdasan, dan kearifan yang tinggi.

e. Evaluator adalah Guru melakukan penilaian terhadap pembelajaran yang dilakukan

Adapun nilai-nilai pendidikan karakter yang juga berpengaruh pada pembentukan sikap nasionalisme diantaranya :

a. Nasionalisme: sikap yang cinta tanah air dan menghargai jasa-jasa para pahlawan yang telah gugur pada masa lampau.

b. Tanggug Jawab: sikap dan perilaku untuk melaksanakan tugas dan kewajibannya yang seharusnya dia lakukan, terhadap diri sendiri, masyarakat, lingkungan (alam, sosial, budaya), negara, dan Tuhan Yang Maha Esa.

c. Disiplin: sikap dan perilaku sebagai cerminan dari ketaatan, kepatuhan dan ketertiban, kesetiaan, ketelitian, dan keteraturan perilaku seseorang terhadap norma dan aturan yang berlaku

d. Toleransi: sikap memahami dan menerima kenyataan, sikap atau tindakan orang lain yang berbeda yang diyakini atau dilakukannya 
e. Kerja Keras: Perilaku yang menunjukkan upaya sungguh-sungguh dalam mengatasi berbagai hambatan guna menyelesaikan tugas (belajar/pekerjaan) dengan sebaikbaiknya

f. Peduli Sosial: Sikap dan tindakan yang selalu ingin memberi bantuan bagi orang lain dan masyarakat yang membutuhkan

Gambaran pelaksanaan secara konkrit dari peran guru sejarah dalam pembentukan karakter dengan menanamkan nasionalisme pada peserta didik dilakukan pada saat diluar pelajaran yaitu sewaktu pelaksanaan upacara bendera. Guru sebagai pembina upacara menyampaikan terhadap peserta didik bahwanya tidak ada jaminan bahwa Indonesia ini akan tetap ada lima puluh tahun ke depan kalau seandainya nasionalisme semakin terkikis dari dalam diri masyarakat Indonesia. Kita lihat keberadaan kerajaan Sriwijaya yang kita anggap negara Nasional Indonesia pertama, yang bertahan lebih kurang 6 abad, begitu juga Majapahit juga eksis beberapa abad kemudian hancur dan hilang. Kemerdekaan Indonesia sendiri sampai sekarang baru berumur 75 tahun. Berkaca dari kejayaan kerajaan Sriwijaya dan Majapahit yang eksis beberapa abad kemudian hilang, oleh karena itu keberadaan Indonesia juga hilang beberapa tahun kedepan kalau para generasi mudanya tidak lagi memiliki rasa nasionalisme.

Nasionalisme merupakan salah satu bahagian dari nilai karakter yang berhubungan dengan lingkungan. Dimana nasionalisme dimaknai dengan kesetiaan, kepedulian dan tanggung jawab. Oleh karena itu guru sejarah dituntut pada proses pembelajaran memiliki kesetiaan, kepedulian dan tanggung jawab dalam pekerjaan sebagai pendidik. Sikap ini ditularkan kepada peserta didik melalui sikap dan tingkah laku guru sejarah tak terkecuali materi yang diajarkan kepada peserta didik. Impelemtasi nasionalisme bisa diimpelentasikan melalui RPP yang dibuat oleh guru sejarah yang diaplikasikan dalam materi pembelajaran sejarah di dalam kelas. Apalagi saat ini guru mempunyai hak untuk merancang RPP sedemikian rupa, sehingga dapat lebih memudahkan guru dalam menentukan metode atau materi yang akan diajarkan dan dapat memberikan pendidikan karakter kepada siswa.

Selain hal tersebut diatas gambaran pelaksanaan pendidikan karakter oleh guru sejarah bisa menularkan karakter tanggung jawab, disiplin dan mandiri. Contohnya guru sejarah memberikan tugas kepada peserta didik berupa tugas individu dan kelompok. Tujuannya adalah mengharapkan peserta didik memiliki rasa tanggung jawab, disiplin dengan waktu pada saat pengumpulan tugas dan mandiri mengerjakan tugas individu. Kemudian karakter jujur, amanah dan arif oleh guru sejarah dilakukan terhadap peserta didik dengan cara melakukan penekanan sewaktu ujian tidak boleh menyontek dan menjawab ujian dengan jujur sesuai dengan kemampuan masing-masing.

Kemudian gambaran implementasi pendidikan karakter oleh guru, guru melakukan tugas secara profesional dengan memeriksa satu persatu tugas yang dibuat oleh siswa. Hal ini dilakukan untuk mengajarkan nilai kejujuran sewaktu mengerjakan tugas atau pekerjaan rumah mereka. Jika ketahuan sama memberi teguran kepada siswa akan berlaku jujur dan bertanggung jawab dalam pekerjaan rumahnya. Selain itu gambaran pendidikan karakter oleh guru sejarah guru mengajarkan agar peserta didik memiliki karakter hormat dan santun terhadap guru atau terhadap orang yang lebih tua.

\section{SIMPULAN}

Guru adalah orang yang bertanggung jawab atas peningkatan moral pelajar juga kemorosotannya. Dengan demikian, tugas guru tidak terbatas pada pengajaran mata pelajaran, tapi yang paling urgen adalah pencetakan karakter murid. Gambaran pendidikan karakter oleh guru sejarah di sekolah seperti dalam proses pembelajaran 
sejarah di dalam kelas. Impelentasi peran guru bisa dicerminkan dengan kepribadian guru. Karena Guru merupakan faktor utama dan berpengaruh terhadap proses belajar peserta didik. Upaya guru sejarah dalam pembentukan sikap nasionalisme peserta didik yaitu mengkaitkan dengan ruang lingkup, materi sejarah, dan RPP mata pelajaran sejarah, metode-metode yang digunakan oleh guru dalam menanamkan nilai-nilai nasionalisme yang ada. Media pembelajaran yang digunakan oleh guru dalam upaya pembentukan sikap nasionalisme siswa

Ke depan perlu menjadi perhatian bersama pada dunia pendidikan untuk mensukseskan program pendidikan karakter pada siswa di era merdeka belajar ini. Hendaknya guru melakukan pendidikan karakter secara berulang dan agar tujuan pendidikan karakter dapat tercapai. Gambaran pendidikan karakter tidak hanya di sekolah, hendaknya dilingkungan masyarakat perlu juga penanaman rasa nasionalisme khususnya bagi generasi muda

\section{DAFTAR PUSTAKA}

Amri, Sofan. 2013. Pengembangan \& Model Pembelajaran Dalam Kurikulum 2013. Jakarta: Prestasi Pustakarata

Johnson, E.B. 2002. Control Teaching and Learning: What It Is and Why It's Here To Study. Thousands Ooks. California: Corwin Press, inc

Kusuma Doni A. 2007. Pendidikan Karakter. Jakarta: Grasindo

Lubis, Erni. 2020. Merdeka Belajar, Bagaimana Jika Sistem Pendidikan Diubah? Diakses darihttps://www.kompasiana.com/amp/sariernilubis/5e18d8e2d541df703563f2b6/m erdeka belajarbagaimana-jika-sistem-pendidik-an-dirubah

Lexi, J, Moleong. 2009. Metodologi Penelitian Kualitatif. Bandung PT. Remaja Rosda Karya

Prayitno, Belferik Manullang. 2011. Pendidikan Karakter dalam Pembangunan Bangsa. Jakarta: Grasindo.

Samani, M., \& Hariyanto. 2013. Konsep dan Model Pendidikan Karakter. Bandung: Remaja Rosdakarya.

Suprapti. 2019. Pengaruh Pendidikan Karakter Dan Lingkungan Sekolah Terhadap Motivasi Belajar Serta Dampaknya Pada Prestasi Belajar Peserta Didik Di SMP Negeri 36 Kota Bandung. Artikel Program Magister Manajemen Fakultas Pascasarjana Universitas Pasundan Bandung.

Sutarjo Adisusilo. 2012. Pembelajaran Nilai Karakter. Jakarta: PT Raja Grafindo

Wartoni. 2019. Merdeka Belajar dan Masa Depan Pendidikan Kita di Era Industri 4.0. Diakses dari https: //www.google.com/search?q=evaluasi+pembelajaran+d i+era=merdeka\&oq=evaluasi+pembelajaran+di+era+merdeka+\&aqs=chrome 